УДК 811.111:378.147

DOI: $\underline{10.35619 / \text { iiu.v2i11.210 }}$

Коваленко Валентина

кандидат педагогічних наук, доцент, доцент кафедри української та іноземної лінгвістики Луцького національного технічного університету, м. Луцьк, Україна ORCID: 0000-0002-8910-2390 e-mail:valenti.g.kovalenko@gmail.com

\title{
ДИДАКТИЧНІ УМОВИ ЕФЕКТИВНОЇ ОРГАНІЗАЦІЇ САМОСТІЙНОЇ РОБОТИ СТУДЕНТІВ 3 АНГЛІЙСЬКОЇ МОВИ
}

Анотація. Підготовка фахівця, який творчо мислить, самостійно поповнює свої знання та застосовує їх на практиці, є основним завданням сучасної вищої школи. Однією з форм організації освітнього процесу у закладі вищої освіти, яка особливо затребувана на сьогодні, $\epsilon$ самостійна робота студентів (СРС). Упровадження ії в навчальний процес $\epsilon$ невід'ємною складовою вивчення кожної дисципліни. Успішність здійснення СРС пов'язана 3 виконанням таких організаційних умов: забезпечення співвідношення обсягів аудиторної і самостійної роботи; підготовка навчальних матеріалів i забезпечення студентів методичними і навчальними завданнями, здійснення контролю і керівництво самостійною роботою студентів. У статті проаналізовано та представлено можливості використання інноваційного сервісу Google Classroom для ефективної організації позааудиторної СРС 3 іноземної мови у ЗВО. Інтерфейс програми оптимізований для роботи на мобільних пристроях, тому студенти можуть навчатися у зручний для них час $\mathrm{i}$ спосіб. Результативність СРС передбачає: індивідуалізацію та автономність навчання, високу внутрішню мотивацію, регуляцію пізнавальної діяльності, вміння самостійно виконувати різні типи завдань і здійснювати самоконтроль і самооцінку. Таким чином можна стверджувати, що Глобальна система надає необмежені можливості і ресурси для задоволення загальнодидактичних принципів організації самостійної роботи студентів.

Ключові слова: самостійна робота, освітній процес, навички, сервіс Google Classroom, дидактичні умови, онлайн навчання.

Постановка проблеми. Особливістю навчального процесу сучасної вищої освіти $\epsilon$ підготовка фахівця, який творчо мислить, ініціативний, самостійно поповнює свої знання та застосовує їх у практичній діяльності; спеціаліста, здатного до саморозвитку, самоосвіти, інноваційної діяльності.

Визначальною тенденцією розвитку сучасної освіти також є перехід від принципу «освіта на все життя» до принципу «освіта впродовж всього життя». Незалежно від зміни орієнтирів і намірів у сфері освітньої політики, основною функцією навчання була і $е$ необхідність передачі молоді змісту соціального досвіду. Тому, коли сьогодні у вишівській освіті відбуваються два протилежні процеси - зростання обсягу інформації і значне скорочення аудиторних годин - особливо важливою $є$ система передачі змісту соціального досвіду. Однією з форм передачі досвіду, яка особливо затребувана в сучасних умовах, $\epsilon$ самостійна робота студентів (СРС). 
Самостійна робота студентів відповідно до статті 50 Закону України «Про вищу освіту» $є$ однією з форм організації освітнього процесу (2017). Самостійна робота - це різноманітні види індивідуальної і колективної діяльності студентів, які вони здійснюють на навчальних заняттях або в позааудиторний час за завданнями викладача, під його керівництвом, але без його безпосередньої участі (Фіцула, 2010, с. 203). Самостійна робота студента $є$ основним засобом засвоєння студентом навчального матеріалу в час, вільний від обов'язкових навчальних занять.

Сучасна європейська система освіти спрямована на перенесення центру тяжіння у навчальному процесі з аудиторних форм навчання на позааудиторні.

У процесі кредитно-модульної системи навчання у закладі вищої освіти значна частина навчального матеріалу виноситься на самостійне опрацювання студентами. Дві третини навчального курсу дисципліни студенти повинні опрацювати самостійно. Впровадження кредитно-модульної системи навчального процесу вимагає, щоб навчання було особистіснозорієнтованим, тобто зміст навчання і шляхи досягнення цілей освіти та професійної підготовки мають відповідати індивідуальним потребам і можливостям студента, a партнерство викладача й студента у навчальному процесі повинно створювати сприятливі умови для педагогічного стимулювання навчальної діяльності. Тому основним завданням викладача вищої школи стає не репродуктивне викладання матеріалу, а організація активної самостійної роботи студентів (Гурська, 2014, с.103).

Упровадження кредитно-модульної системи навчання робить самостійну роботу студентів більш організованою, оскільки кожне заняття проводиться як мікромодуль і кожен студент перебуває під систематичним контролем викладача.

Аналіз останніх досліджень 3 проблеми. Ефективно спланована та організована самостійна робота студентів - це одна 3 умов, необхідних для формування в них пізнавальної самостійності. Вона підвищує розумову активність студентів у процесі осмислення та засвоєння нових знань. Тому велика увага приділяється саме розробці дидактичних основ організації самостійного навчання студентів.

Відомі педагоги-дослідники: А. Алексюк, Л. Арістова, Ю. Бабанський, О. Баранніков, В. Безпалько, В. Бондар, В. Буряк, В. Вертегел, Б. Голант, О. Заїка, С. Дяченко, Б. Ссипов, Л. Заякіна, Н. Калашник, Л. Кандибович, В. Казаков, Л. Коротаєв, І. Лернер, О. Линда, П. Маланюк, В. Мороз, О. Мороз, Р. Нізамов, В. Паламарчук, П. Підкасистий, В. Сластьонін, О. Сотнікова, О. Спірін, Н. Тализіна, А. Усова, Т. Шамова у своїх працях досліджували різні аспекти самостійної роботи та акцентували увагу на необхідності добре спланованої організації самостійного навчання учнів під час оволодіння знаннями.

Когорта педагогів (А. Алексюк, А. Аюрзанайн, Г. Костюк, 3. Курлянд, П. Підкасистий, А. Семенова, Р. Хмелюк та ін.), високо оцінюючи роль самостійної роботи в процесі навчання, наголошують, що вона виступає чи не єдиним способом виховання самостійності у засвоєнні знань, формуванні умінь і навичок.

Вивчення напрацювань зазначених вчених доводить, що самостійна робота студентів у процесі навчання дає можливість успішно розв’язати такі завдання:

а) цілеспрямовано підвищувати свідомість студентів, що сприяє кращому засвоєнню ними матеріалу;

б) розвивати в них уміння знаходити нові шляхи для оволодіння знаннями;

в) застосовувати набуті знання як засоби до дій для оволодіння новими знаннями в нових умовах;

г) сприяти розвиткові пізнавальних здібностей студентів (спостережливості, логічного мислення, творчої активності); 
д) прищеплювати культуру розумової та фізичної праці, навчити самостійно досягати поставленої мети.

Аналіз педагогічної літератури дає підстави зробити висновок про відсутність єдиного тлумачення поняття «самостійна робота». Часто під терміном «самостійна робота» одні розуміють «навчальне завдання», інші - «самостійну діяльність». Таке зміщення розуміння змісту завдання та самого процесу діяльності ускладнює формулювання єдиного поняття про самостійну роботу.

Ми будемо розглядати «самостійну роботу» як форму організації навчальної діяльності, що характеризується такими ознаками:

- наявність мети самостійної роботи;

- наявність конкретного завдання;

- чітким визначенням форми подачі результатів самостійної роботи;

- $\quad$ визначенням форми перевірки результату самостійної роботи;

- обов'язковим виконанням роботи власними силами кожним студентом після одержання завдання.

Мета статті - проаналізувати та представити можливості використання інноваційного сервісу Google Classroom, який може успішно й ефективно застосовуватися для організації позааудиторної самостійної роботи студентів з іноземної мови у ЗВО.

Виклад основного матеріалу дослідження. Іноземна мова $є$ додатковим засобом для розширення світогляду особистості майбутнього спеціаліста, здійснення міжкультурної комунікації, а отже, особливої уваги в освітній політиці на сьогодні заслуговує самостійна робота студентів саме з іноземної мови.

Зміст самостійної роботи з іноземної мови спрямований першочергово на засвоєння навчальної програми, а успішність здійснення СРС пов'язана 3 виконанням низки організаційних умов, а саме:

- забезпечення співвідношення обсягів аудиторної і самостійної роботи;

- підготовка навчальних матеріалів і забезпечення студентів необхідними методичними і навчальними завданнями;

- $\quad$ здійснення контролю і керівництво самостійною роботою студентів.

Формування у студентів потреб і мотивів до активної самостійної роботи відбувається через спонукання (наказ, жорстка вимога) викладача. Проте цей спосіб не є ефективним, оскільки будь-яка діяльність, що не викликає в людини професійного інтересу, малопродуктивна. Значно ефективнішим способом формування у студентів потреб і мотивів до самостійної роботи є розвиток пізнавального інтересу до предмета, який вивчається, та процесу оволодіння ним. Діяльність, що має у своїй основі глибокий інтерес не лише до кінцевого результату, а й до ії̈ процесуальних компонентів, $є$ найпродуктивнішою, адже саме від неї людина отримує найбільше задоволення. Студент у такому випадку сам знаходитиме час для предмета, який йому сподобався. Зрозуміло, що викликати інтерес до навчальної дисципліни, її змісту повинен викладач.

Виховання у студентів навичок самостійної роботи з навчальним матеріалом, науковою і навчально-методичною літературою належить до першочергових завдань вищої школи. Адже одночасно студенти виховуватимуть у собі організованість, системність, діловитість, зосередженість, без чого їм не обійтися в майбутній професійній діяльності. У зв'язку 3 великим навчальним навантаженням та дефіцитом часу важливе значення для студента має раціональне планування самостійної роботи. План допомагає правильно розподіляти й економно використовувати свій час, а обгрунтування обсягу, змісту, послідовності роботи 
впродовж певного часу надає роботі цілеспрямованості, творчого характеру (Гуревич, 2018, c.11-15).

Самостійне набуття знань не повинно носити пасивний характер, навпаки, студент від початку включається в активну пізнавальну діяльність. Викладачу необхідно максимально задіяти всі задатки студентів, їхні здібності до певного виду мовленнєвої діяльності.

У новому контексті вищої освіти відповідальність за вдосконалення знань, умінь і навичок несе не лише заклад вищої освіти, але й сам студент. Тому студент повинен володіти широким спектром умінь і навичок самоосвіти, першочергово навичками роботи в Інтернеті, використання можливостей якого все більше входить у навчальний процес. Інтернет є засобом комунікації у світі, тож і викладачі, і студенти тепер мають численні можливості для проблемного навчання та телеколаборації.

Процеси інформатизації сучасного освітнього простору нерозривно пов'язані 3 активним упровадженням інноваційно-інформаційних технологій в навчальний процес, що стає невід'ємною складовою вивчення будь-якого предмета.

В. Гриценко та I. Юстик (2015) виокремлюють декілька основних сучасних тенденцій розвитку інформаційно-комунікаційних технологій в освітньому процесі:

- створення єдиного освітнього простору;

- активне запровадження сучасних засобів та методів навчання з орієнтуванням на інформаційні технології;

- поєднання традиційного та комп'ютерного навчання;

- створення системи гібридної освіти;

- постійний професійний розвиток викладача з метою продукування ним інформаційних технологій для навчання;

- зміна діяльності викладача на розробку нових засобів для підвищення його творчої активності, збільшення рівня технологічної та методичної підготовки;

- формування системи безперервного навчання - універсальної форми діяльності, котра спрямована на постійний розвиток протягом життя.

Сьогодні тотальна інформатизація суспільства призводить до широкої популяризації новітніх методів навчання 3 використання Інтернет та комп'ютерних ресурсів. Тому не $\epsilon$ дивним той факт, що Інтернет тісно ввійшов у наше щоденне життя.

Останні два роки в навчальному процесі з вивчення англійської мови на кафедрі успішно використовується інформаційно-освітній сервіс Google Classroom для організації i проведення самостійної роботи студентів з англійської мови. Сервіс безкоштовний, простий i зручний у користуванні. Для роботи 3 ним викладачеві не потрібні глибокі знання інформаційних технологій. Доступ до нього може отримати будь-який користувач Google. Робота в сервісі може здійснюватися як з персонального комп'ютера, так і з будь-якого гаджету, підключеного до Інтернету. Викладачі використовують як традиційні, так і новітні методи навчання англійської мови. Google Classroom не замінює викладача, а лише слугує як допоміжний інструмент. Усі можливості, які надає Google Classroom, будуть ефективними лише тоді, коли викладач продумав, вдало розробив програму курсу, підготував матеріали, презентації, аудіозаписи, вправи тощо.

Особливо успішним виявилося використання цього сервісу для роботи 3 навчання та засвоєння лексики і тренування навичок читання. Студентам пропонується: вивчити нову лексику шляхом прослуховування аудіо-запису зі словами та виразами; повторити за диктором-носієм мови; аудіювання речень 3 новими лексичними одиницями; робота 3 онлайн чи паперовими словниками; аудіювання базового тексту 3 підручника New Destinations (студенти тренуються читати текст, відтворюючи інтонацію, ритм, наголос 
диктора); аудіювання діалогів та монологів з наступним виконанням вправ на перевірку. У завданнях для самостійної роботи містяться вправи на закріплення, повторення i поглиблення тем, які вивчалися в аудиторії, а також їх можна використати для попереднього ознайомлення 3 лексичним матеріалом нового змістового модуля, що надає можливість студентам заздалегідь підготуватися до занять. Через сервіс студенти також отримують завдання з письма, виконують їх онлайн в Google Docs і прикріплюють свої роботи-відповіді до завдання (Губіна, 2019, с.185). Така робота вимагає від користувачів Google Classroom організованості та навичок систематичної праці відповідно до вказаних термінів. На сьогодні інтерфейс програми оптимізований для роботи на мобільних пристроях, отже, студенти мають можливість навчатися у будь-якому місці та у будь-який час: у транспорті, у кафе, вдома, чи просто, йдучи містом, слухати запис в навушниках. Можна не лише слухати, а й одночасно читати текст $з$ екрану смартфона. Студенти, які брали участь в апробації такої технології навчання, задоволені навчанням 3 допомогою сервісу Google Classroom.

Висновки і перспективи подальших розвідок. Оскільки результативність СРС передбачає: індивідуалізацію навчання, високу внутрішню мотивацію, регуляцію пізнавальної діяльності, автономність навчання, вміння самостійно виконувати різні типи комунікативно-пізнавальних завдань, особливо творчі й продуктивні, вміння здійснювати самоконтроль і самооцінку, то можна стверджувати, що Глобальна система надає необмежені можливості і ресурси для задоволення загальнодидактичних принципів організації самостійної роботи студентів. Поєднання самостійного онлайн навчання студентів 3 навчанням в аудиторії під керівництвом викладача сприяє індивідуалізації навчального процесу, наближенню його до потреб кожного студента, незалежно від рівня його початкової підготовки. Застосування сервісу Google Classroom змінює ставлення викладача до роботи, змушує працювати творчо, бути завжди онлайн зі студентами.

Перспективи майбутніх досліджень вбачаємо у подальшому вивченні змін та оновлень cервісу Google Classroom 3 метою розширення застосування його можливостей для ефективної організації самоосвіти студентів заочної та дистанційної форм навчання, а також для підготовки конкурентоспроможних фахівців денної форми навчання.

Можна відзначити надзвичайну важливість у роботі викладача англійської мови як іноземної використання комп'ютерно-орієнтованого навчання в цілому та змішаного зокрема.

\section{СПИСОК ВИКОРИСТАНИХ ДЖЕРЕЛ}

Міністерство освіти і науки України, (2017). Закон Украӥни «Про вищу освіту». Режим доступу: http://osvita.ua/1 egixslation/law/2231/ [Дата звернення 21січня 2020].

Фіцула, М. (2010). Педагогіка вищяої иколи. Київ: Академвидав. 456 с.

Гурська, О. (2014). Місце та роль самостійної роботи студентів у навчальному процесі. Витоки педагогічної майстерності. № 13. С.103-107.

Гуревич, Р. та Кадемія, М. (2018). Інноваційні технології у закладах вищої освіти. Сучасні інформаційні технології та інноваційні методики навчання в підготовці фахівців: методологія, теорія, досвід, проблеми. Вип. 51. С. 11-15.

Гриценко, В. та Юстик, I. (2015). Використання сервісу Google Classroom для управління освітніми процесами. URL: https:// www.cuspu.edu.ua/ua/ntmd/konferentsiy/2015-10-06-0617-54/\%20sektsiia-4/3930-vykorystannya-servisu-google-classroom-dlya-upravlinnya \% $20 \quad$ osvitnimy-protsesamy. [Дата звернення 21січня 2020]. 
Губіна, А. та Мартинюк, А. (2019). Можливості сервісу Google classroom у навчанні іноземної мови у ЗВО. Наукові записки Національного університету «Острозька академія»: серія «Філологія». Острог: Вид-во НаУОА. Вип. 5(73), березень. С. 184-187.

\title{
REFERENCES
}

Ministry of Education and Science of Ukraine. (2017). Zakon Ukrainy «Pro osvitu» [The Law of Ukraine «On Education»]. [on line] URL: http://osvita.ua/1egixslation/law/2231/ [Data zvernennia 21 sichnia 2020]. (in Ukrainian)

Fitsula, M. (2010). Pedahohika vyshchoi shkoly [Higher School Pedagogy]. Kyiv: Akademvydav, $456 \mathrm{~s}$. (in Ukrainian)

Hurska, O. (2014). Mistse ta rol samostiinoi roboty studentiv u navchalnomu procesi [Student's Independent Work: Its Place and Function in the Educational Procedure]. Vytoky pedahohichnoi maisternosti. No13. S.103-107. (in Ukrainian)

Hurevych, R., Kademiya, M., Umanets, V. (2018). Innovatsiini tekhnolohii u zakladakh vyshchoi osvity [Modern Technologies in Higher Educational Establishments] Suchasni informatsiini tekhnolohiï ta innovatsii metodyky navchnnia v pidhotovtsi fakhivtsiv: metodolohiia, teoriia, dosvid, problemy. 2018. Vypusk 51. S. 11-15. (in Ukrainian)

Hrytsenko, V. ta Yustyk, I. (2015). Vykorystannia servisu Google Classroom dlia upravlinnia osvitnimy protsesamy [Use of Google Classroom Service for the Guidance of Educational Procedures] [on line] URL: https://www.cuspu.edu.ua/ua/ntmd/konferentsiy/2015-10-06-06-1754/\%20sektsiia-4/3930-vykorystannya-servisu-google-classroom-dlya-upravlinnya\%20osvitnimy-protsesamy. [Data ostannoho zvernennia 21 sichnia 2020]. (in Ukrainian)

Hubina, A. ta Martyniuk, A. (2019). Mozhlyvosti servisu Google Classroom u navchanni inozemnoi movy u ZVO. [Google Classroom Service in Teaching a Foreign Language at Universities]. Naukovi zapysky Natsionalnoho universytetu "Ostrozka akademiia": seriia «Filolohiia». Ostroh: Vyd-vo NaUOA. Vyp. 5(73), berezen. S. 184-187. (in Ukrainian)

\section{DIDACTIC CONDITIONS FOR EFFECTIVE ORGANIZATION OF STUDENT'S INDEPENDENT WORK IN LEARNING ENGLISH}

\author{
Valentyna Kovalenko \\ $\mathrm{PhD}$ in Pedagogy, Associate Professor. \\ Associate Professor at the Department of Ukrainian and Foreign Linguistics of \\ Lutsk National Technical University, \\ Lutsk, Ukraine \\ ORCID: 0000-0002-8910-2390 \\ e-mail:valenti.g.kovalenko@gmail.com
}

\begin{abstract}
Training of qualified, creative, effective specialists capable to enlarge their professional knowledge and to use it in their work is the main task of modern higher school. The country needs new professionals with modern knowledge and competences. Nowadays it is more important for a young person to have learnt how to learn than to be taught. The tendency of the development of modern education is transition from the "education for the whole life" principle to the "lifelong learning" principle. Student's independent work (learning) is the form of educational procedure organization that is greatly needed at the present time. Its introduction into educational procedure becomes integral part of every subject study. It involves responsibility for one's own learning. A shift is made from teaching to learning. The success of the work depends on the
\end{abstract}


following conditions: personal involvement and motivation; individual training; a feeling of progression; teacher's help and guidance; educational materials, methods and tasks; testing and evaluation of the work carried out. The article deals with the issues considering possibilities of Google Classroom service as an additional means of learning English independently. The author analyses and presents language learning activities of the service for student's independent work, namely for learning and training lexical material of the English language. By means of the service students receive assignments in different language activities and have to fulfill them up to some deadline period. Service interface is adapted for work with various mobile devices, so students can use it whenever and wherever they like. Among educators and learners online teaching is accepted as a viable component in teaching and learning. It is easy to have the Internet connection anywhere. Global system gives us unlimited possibilities and resources to provide general didactic principles for ensuring student's effective independent work.

Keywords: independent work (learning), educational procedure, habits, Google Classroom service, didactic conditions, online teaching.

Стаття надійшла до редакиії 08. 02. 2020p. 